\title{
NE VEDD KOMOLYAN! VAGY MÉGIS?
}

Nagyon sok szó esik manapság a diszciplínák közötti viszonyokról. Míg a magánéletben, ha nem is kizárólagos, de többségi preferencia a monogámia, addig a tudományban többnyire elismerés övezi a poligámiát. Így például az én szakmám, az eredendően politikatörténet-centrikus, az államok közötti kapcsolatokra koncentráló történettudomány az elmúlt mintegy másfél évszázad során termékeny viszonyba keveredett a filozófiával, a közgazdaság-tudománnyal, a pszichológiával, a szociológiával, az antropológiával, az irodalomtudománnyal és így tovább. A fáradhatatlan, vonzerejét nem vesztő Klió viszonyai korántsem voltak plátóiak: megszületett többek között a gazdaságtörténet, a társadalomtörténet, a pszichohistória, az emóciók története, sőt, a hálózatok problémáit vizsgálva a matematikával is összeszürte a levet, s így a kliometria kistestvéreként megkapta a hálózattörténetet.

Egy csábítónak azonban csak ritkán enged Klió, ez pedig a humor. A humornak is van persze története, de ez nem új minőséget teremtő kapcsolat. Milyen a kapcsolat más tudományágak és a humor, és általában a tudomány és a humor között? Erre kapunk választ egy 65 éve monogámiában élő neves magyar tudóstól, Szentes Tamástól, a globalizálódó világgazdaság múltját, jelenét és jövöjét tág perspektívában kutató gondolkodótól, aki a közelmúltban megjelent könyve előszavában a következőket írja: „Ami... a tudomány és a humor viszonyát illeti, bátorkodom kijelenteni, hogy a tudomány müvelése kellö humor és önirónia nélkül nemcsak megalapozatlan elbizakodottsághoz, sőt nagyképüséghez vezet, hanem olyan valamiféle örök és univerzális igazság kereséséhez vagy pláne meglelésének tévhitéhez, amilyen a valóságban nem létezik.” Sőt, viszi tovább a gondolatot a világhírü tudós, aki jóval több mint fél évszázada oktatóként, kutatóként és számos nemzetközi szervezet munkatársaként, tanácsadójaként foglalkozik a globális gazdasági és társadalmi egyenlőtlenségek dinamikájával, ,,..az életünkben, mindannyiunk életében tapasztalható visszásságok, bosszankodások, csalódások enyhitésére, sőt a katasztrófák s szenvedések könnyebb elviselésére is a legjobb gyógyszer a humor, még akár a morbid humor is". A könyv egy akadémiai rendes taghoz illően jól áttekinthetően szerkesztve, rendszerezve öt fejezetben tekinti át több évtizede gyüjtögetett, humorral átitatott megfigyeléseit a tudományos és mindennapi élet jelenségeiről. Hogyan is határozza meg az akadémiai rendes tag fogalmát? „,...az MTA rendetlen tagjaitól eltérően időben érkezik az ülésekre, ott rendesen viselkedik, fel sem szólal, vagy ha mégis, felszólalásával nem zavarja a többieket vagy az elnökséget, bármit megszavaz, továbbá a kiosztott dokumentumok és saját iratai között rendet tart, vagyis magatartása egyáltalán nem kifogásolható”. Nemzetközi tanácsadói tevékenysége során szerzett ta- 
pasztalataira épül „,pontos” meghatározása az ENSZ Alapokmányáról: „,azoknak a szépen hangzó, kétségkivül a nemzetközi békét és együttmüködést, a társadalmi nyugalmat és igazságosságot célzó (bár helyenként ellentmondásos) elveknek és követelményeknek a gyüjteménye, amelyeknek az érvényesitését az ENSZ tagállamai csupán egymástól kérik számon, miközben maguk többnyire figyelmen kivül hagyják”. Élettapasztalata mondatja vele az Európai Unióról: „,...azoknak az európai államoknak a közös szervezete, amelyek még a gazdasági uniónak a közös pénzre vonatkozó követelményének sem képesek együttesen, minden ágra kiterjedöen eleget tenni, még kevésbé képesek a tagok egyenlöségét, a döntéshozatal demokratikus rendjét biztositani, ami egy politikai és intézményi értelemben vett unió sikeres müködésének a feltétele”. Fö kutatási területe sajátosságaira reflektál a fejlődés-gazdaságtan definíciója: „... a fejlődésnek egy olyan gazdaságtana, amelyet nem fejlödö országok gazdaságának a tanulmányozására hoztak létre abban a hiszemben, hogy más országok fejlödése problémamentes, és ezért nem is igényel vizsgálatot”. Tágabb szakmájának önkritikus definíciója: „, k közgazdász olyan, többnyire diplomás egyén, aki a közgazdaságtudomány ismeretanyaga egy részének elsajátitása alapján abban a hiszemben tevékenykedik, hogy érti is, vagy pláne javithatja a gazdaság jelenségeit és folyamatait."

De miért is olyan fontos a nagy tekintélyü tudós számára a humor? Tudós munkájáról tudományos folyóiratban megjelenő írás aligha nélkülözheti a humorelmélet segítségét e kérdés megválaszolásában! Az elmélet mindenekelőtt a fogalom pontos meghatározására késztet. Az, amit a hétköznapi életben humornak nevezünk, az lehet irónia, szarkazmus, gúny, cinizmus, hatásmechanizmusát tekintve célba veheti a kognitív funkciókat vagy az emóciókat, szelepként segíthet kisebb vagy nagyobb konfliktusok feloldásában, de rosszul adagolva generálásában is. Kreálhatja véletlen elszólás, de nagyon tudatosan is alkalmazható. Lehet kard vagy pajzs, agresszív vagy defenzív, erösítheti kiegyensúlyozott személyiségü emberek magabiztosságát, de labilis tudatállapotúakat bármely formájában a pokol tornácára is juttathat. Kifejezhet lekezelő fölényességet, de értelmezhető válságból felemelő, szolidaritást kifejező gesztusként is. Egy jó időpontban, optimális közegben, jól célzottan elhelyezett poén felemelhet, de meg is semmisíthet.

Hogyan helyezhető el Szentes Tamás humora ebben az elméleti keretben?

Az eddigi idézetek humorának egyik jellegzetességét, a kognitív elmefunkcióinkat célzó, tágabb értelemben vett társadalomtudományi öniróniát illusztrálják. Erre további példa „félreeértelmező szótárának” három, különböző módokon nevettető, de egyformán keserü címszava. Fejlődés: „...általában az a folyamat, amelyben az emberi társadalom újabb és újabb technikai illetve technológiai vívmányokkal, valamint forradalmak vagy reformok útján megváltoztatott gazdasági, politikai és intézményi rendszerekkel próbálja megoldani a mindezek révén saját maga által elöidézett egyre súlyosabb problémákat...”. Haladó: „, halakra kivetett adó”, liberalizmus: „,az Amit szabad nekem, azt nem szabad neked-elv kifejezése”. Találunk itt 
azonban nem egy, pusztán a szerző kreatív nyelvi fantáziáját tükröző definíciót is: piano: ,alkohol fogyasztásának szigorú tiltása mellett élvezett halk zene”.

A könyv második része ismert bölcsességeket, mondásokat „értelmez” újra: Errare humanum est: „az emberiség egy nagy tévedés”, ora et labora: „munka közben mindig nézd az órát, nehogy véletlenül is tovább dolgozz a kelleténél”. Ugyanennek a mondásnak játékos helyett politikus értelmezése: „Imádkozzál és dolgozzál, mondta a rabszolgatartó ültetvénytulajdonos annak a megkeresztelt néger rabszolgának, akit éppen megkorbácsolt.” Varietas delectat: „...pártot, illetve politikai meggyözödést váltogatni élvezetes".

Élvezettel, helyzetkomikumi ábrázolásmóddal ábrázolja a mindennapi élet kisebb-nagyobb csapdáit: „Ha a számítástechnikai szakember arra hivatkozik, hogy »A számítógépnek lelke van«, csupán azt fejezi ki, hogy fogalma sincs a hiba okáról." Itt, a mindennapi törvényszerüségek fejezetében összegezi néhány általános, a humor és az empíria határvidékéhez kapcsolódó megfigyeléseit: „A bunkóság egyenesen arányos a gyors meggazdagodással.” Az akasztófahumor sem áll távol szerzőnktől: ,, Segíts magadon, az Isten is megsegít! szólt a cserbenhagyó autóvezetö az általa elgázolt haldoklóhoz!”

C. Northcote Parkinson és Peter Lawrence nyomába szegődve gondolja újra „,törvényeiket”. A szellemes megfogalmazások itt is sajátos, keserúen melankolikus hangulatot teremtenek: „Csak szegényektöl kérj áldozatvállalást, mert nekik már van tapasztalatuk benne.” „Egy eszme lejáratásához az is elég, ha megpróbálják azt ...megvalósítani!"

Igazán otthon azonban a tudomány és a felsőoktatás világában érzi magát Szentes Tamás, ehhez kapcsolódnak legszellemesebb megfigyelései, így például: „,Tudásunk gyarapodásával egyre nagyobb mértékben és gyorsabban nö azoknak a problémáknak és összefüggéseknek a száma, amelyek okairól még nem tudunk semmit."

A tekintély sokszor együtt jár a szellemességgel, írta egy rendkívül sikeres flamand író, John Vermeulen. Szentes Tamás egyénisége, munkássága meggyőzően példázza ezt a tételt.

A recenzens azt reméli, hogy mindezek alapján sokan kapnak kedvet e könyv olvasásához, azonban figyelmeztetnem kell öket arra, hogy ezt semmiképpen se tegyék az olvasást fontos dokumentumok tanulmányozásának álcázva unalmas értekezleteken, rendezvényeken. A humorfogyasztás fiziológiai következményei, a halk kuncogástól a hangos, visszafojthatatlan nevetésig, ugyanis elárulhatják őket.

(Szentes Tamás: Ne vedd komolyan! Vagy mégis? avagy hogyan viseljük el irónikus humorral életünk visszásságait. „,Ridendo dicere verum”. Budapest: Tinta Könyvkiadó, 2020)

Pók Attila 